Copyright (C) 2019 by Academic Publishing House Researcher

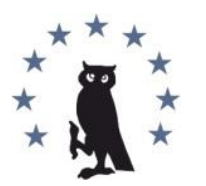

Published in the Russian Federation

European Researcher. Series A

Has been issued since 2010.

E-ISSN 2224-0136

2019, 10(3): 141-147

DOI: 10.13187/er.2019.3.141

www.erjournal.ru

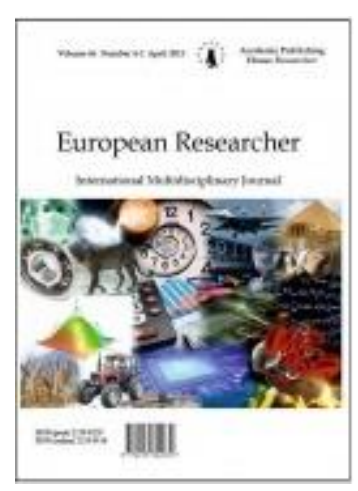

\title{
Missle Shield Crisis and Putin's Effect of USA-Russia Relations
}

\author{
Semih Ecin a, Filiz Katman a, * \\ a Energy Politics and Markets Research Center, Istanbul Aydin University, Turkey
}

\begin{abstract}
This article is about that effects of missile shield project over regional politics and RussiaUSA relations. It will try to analyze Putin's policies and strategy to struggle USA. Article aims to explain cases by the historical progress. How policies evolved between Russia and USA. USA and Russia are most powerfull of the world. The relations of the USA and Russia, who were at the same side in World War I, became a struggle of power with Tsarist Russia converting into the Soviet Union. Obama, came to power in 2008, took in means of relations with Russia is quitting the missile shield system project. Naturally this step was welcomed by Russia. After the USA retracting from implementing missile shield to the Eastern Europe, Russia has declared that it has retracted from implementing missile shield to Kaliningrad. These events are considered as developments which lowered the tense in the USA-Russia relations dramatically. Another important event is Russia's acceptation about the USA's sanctions on Iran. Caucasia and Central Asia policies adopted by Putin's Russia within the scope of the USA-Russia relations, after Obama was elected as the president of the USA, has caused conflict among these two countries. This article has been prepared to present the relations of these two foremost countries specifying the research in Russia during Putin's term in order to understand how the relations came to this state makes the study important. Thus, it is intended to explain how the relations came to this state and present the effects of the relations today. Also, presenting the impacts of presidency changes in these countries is among the aims of the article.
\end{abstract}

Keywords: USA Russia Relations, Putin, Obama Nato, USA, Russia, Iran.

\section{Introduction}

When Putin came to governance, Bill Clinton was the president of the USA and just one year later in 2001 George Bush took the office of the USA president. In September $11^{\text {th }} 2001$ caused a partnership between Russia and the USA to act against terrorism but with George Bush applying hard power policies, two country's relations got effected and caused Putin's approach on relations with the USA effect unfavorably. Again, at the same time having Russia's economy on the rise is considered to be an additional effect for Moscow setting Washing to the secondarily importance. First, this fact should be known about Putin's approach on relations with the USA.

After the end of the Cold War, it was necessary to acknowledge Russia as an important actor by other world countries including the USA. The reason for this is considered as nuclear weapon power owned during the Soviet Union times. As a matter of fact, just after the Cold War the most important topic within the scope of the USA-Russia relations was the nuclear weapon that Russia

\footnotetext{
${ }^{*}$ Corresponding author

E-mail addresses: filizkatman@aydin.edu.tr (F. Katman), semihecin@hotmail.com (S. Ecin)
} 
owns (Gözen, 1997: 75). Nuclear weapons, having decisive roles on the communications between both parties, shows that it has a significant effect on other topics directly or indirectly.

Missile Defense System begins with the Star Wars project, and main target is establishing to Global Missile Defense System. The system had completed the first stage with missile launchers in California and Alaska. USA's goal is to prevent the threat away from the main continent.

For this reason, U.S. began to look location in Europe in order to protect own military bases from the threat of medium-and short -range missiles. In the beginning of 2007, The United States has offered to establishment missile defense and the radar system in both Poland and the Czech Republic, against to threat of Iranian ballistic missiles. After then in 2008, the project was continued by the new president Obama. In 2009, after the Russian objections, "European Ballistic Missile Defense Program" canceled and instead under the name of "phased adaptive approach" was launched a new program. So, known as missile shield project converted into a NATO project.

One of the main concerns of USA and Europe is Iran's purpose that obtain a nuclear capability. However, Iran is not single actor in region that will feel missle shield effects. Russia as a non-NATO member country, also started to feel this pressure and countered by its own capabilities.

The first imperative of Russia's foreign policy consensus is maintaining the country's position as a nuclear superpower. The centrality of preserving Russia's parity with the only other nuclear superpower, the United States, explains Moscow's eagerness to engage in strategic arms control negotiations with Washington. At the same time, Putin's assertive pursuit of this goal accounts for the vehemence with which Moscow has opposed anything that could weaken this strategic parity, such as NATO's missile defense system in Europe. It is hardly surprising, then, that the claims of top U.S. and NATO officials that the system poses no threat to Russia's nuclear deterrence have fallen on deaf ears. As Putin declared in his speech at the Russian Foreign Ministry last July, the missile shield allegedly "upsets the strategic balance" that is, it weakens Russia's status as a nuclear superpower.

\section{Discussion}

\section{The Perception of USA}

The USA's Post-Cold War policies are based on decreasing the dependence of other countries to Russia which is reforming its' targets. Being aware of this means lowering the dependence in terms of energy, the USA has wanted to lower the European countries dependence of energy to Russia (Özkan, 2010: 118). In addition to this situation, Russia and the USA confronted each other many times and the relations maintained under the influence of this fact.

Russia and the USA engaging each other in Mid-Asia, did not engage each other much at first in Middle East where the USA is strong after The Cold War. The USA's invasion of Iraq, interfering to the occurrences in the region shows the USA's control in the region after the Cold War (Kurt, 2014: 168). Thus, it can be said that after the end of the Cold War at first the USA-Russia relations continued towards the USA's interests in terms of Middle East. In other words, it is not correct to state that the occurrences in the Middle East affected the USA-Russia relations.

At first, after the end of the Cold War, it was necessary to acknowledge Russia as an important actor by other world countries including the USA. The reason for this is considered as nuclear weapon power owned during the Soviet Union times.USA-Russia relations took a turn after the dissolving of the Soviet Union, which is only natural. At that time the USA's efforts were based on preventing another super power to emerge in the world which could compete its power. This case which could be observed with the relations with Russia, points that the new order in the world is governed by the USA. Likewise, emphasizing about how the world needs the USA various times, supports this statement. Then it could be said that the USA's efforts, involving relations with Russia at the beginning of the Cold War, aims to fill the power and influence gap that has merged after the dissolving of the Soviet Union (Canar, 2012a: 51). Besides that, the USA also has aimed to prevent another country to fill the mentioned power and influence gap and gain power.

In order to analyze the USA-Russia relations correctly after the Cold War period. Thus, it is clear that the USA develops policies and takes actions in order to become the supreme power in the world. By the Putin era, it shows that Russia is again going through a reformation process and pursues the goal to become a decisive country in the world once again. 
The September 11 incident is a matter that has to be mentioned among the occurrences after the Cold War not only for its effects on the USA-Russia relation but for it is a significant event for all of the countries around the world, which could be considered as a turning point. After the attacks took place in the USA on $11^{\text {th }}$ of September 2001, is another time when the USA uses military intervene as an option. At this time the USA's aim is considered as furthering its dominance in the world. When these developments are considered in terms of the USA-Russia relations, they point out as developments of fighting against terrorism after the Cold War. In addition to that September 11 is considered as the turning point in the world in means of politics and military (Özkan, 2011: 53).

In the Post-Cold War era another event that is observed within the scope of the USA-Russia relations is the missile shield system project.

Missile Defense System begins with the Star Wars project, and main target is establishing to Global Missile Defense System. The system had completed the first stage with missile launchers in California and Alaska. USA's goal is to prevent the threat away from the main continent.

For this reason, U.S. began to look location in Europe in order to protect own military bases from the threat of medium-and short -range missiles. In the beginning of 2007, The United States has offered to establishment missile defense and the radar system in both Poland and the Czech Republic, against to threat of Iranian ballistic missiles.

After then in 2008, the project was continued by the new president Obama. Obama's becoming the president of the USA is an event that had significant effects on many points, especially on the USA-Russia relations. That is because, with Obama becoming the president, the military intervention policy that the USA had adopted has become less considerable. Thus, the USA will be adopting a policy that is open to develop strategic relations and will involve all of the country's interest including Russia.

One of the first things that Obama has done when he came to power in 2008 as the head of the USA was to oppose to the missile shield system project. This was considered as change of behavior in means of the USA-Russia relations. As a matter of fact, in Obama's term the USA-Russia relations were specifically designated as open to dialog about banning nuclear weapons (Kamalov, 2009: 68). This shows that the USA-Russia relations will continue differently during Obama's presidency, compared to the past.

During Obama's presidency one of the significant incidents within the scope of relations with Russia was Russia's assault on Southern Ossetia. Georgia has a strategic importance due to its pipeline projects as well as being an important step of the project of NATO's expansion to the east. The USA government did not support Georgia during Obama's time as it had supported pretty much during Bush's time. These developments are considered as Obama administration has prioritized other international events and at the time wishes to maintain communications with Russia by not disturbing it (Öztürk, 2010).

Another matter that has to be addressed during Obama's term within the scope of the USARussia relations is the nuclear installments of Iran. Russia is supportive to the Iran's nuclear advances because Iran is an important and fine market for Russia (Telatar, 2012: 60). On the other hand, the USA's position towards Iran is obvious. That is why Iran and nuclear arming is an important point for the USA-Russia relations. While Obama is continuing his post as the president there has been some loosening about this topic and it is known that there has been some positive developments about the sanctions on Iran. This circumstance is again considered as a result of interests considered by Obama's presidency with the aim of taking steps to establish a dialog.

Arab Spring is another significant development during Obama's presidency. In terms of the USA-Russia relations, Arab Spring is another topic that caused conflict between both parties. Especially about Syria where the fight still continues, the difference in opinion between the USA and Russia causes regional and global scale outcomes. Russia's supporting the current government and the USA's opposing to that by stating the necessity of change of government are considered as the main actors of the jamming for the solution for Syria. Because of one of Russia's largest military base is based in Syria, is the fundamental reason for Russia's approach towards Syria in means of Arab Spring (Göngen, 2014: 13). Thus, Russia does not wish to lose its interest and opposes to the USA's and other country's any suggestion of reformation in Syria. Today, events in Syria are active topics in terms of course of the USA-Russia relations. Both countries have different strategy and partners in the region. 
In 2009, after the Russian objections, "European Ballistic Missile Defense Program" canceled and instead under the name of "phased adaptive approach" was launched a new program. So, known as missile shield project converted into a NATO project. Thereafter Romania, Poland, Estonia and Finland was confirmed the program.

On 19 and 20 November 2010, the project was approved during NATO summit in Lisbon. The Summit Declaration stated that "Missile defense will become an integral part of our overall defense posture," and that the program will be "based on the principles of the indivisibility of allied security and NATO solidarity, equitable sharing of risks and burdens, as well as reasonable challenge, taking into account the level of threat, affordability and technical feasibility, and in accordance with the latest common threat assessments agreed by the Alliance" (NATO Lisbon Summit Declaration. November 20, 2010).

\section{The Perception of Russia}

It is known that before Vladimir Putin became the president of the Russian Federation, the previous president Boris Yeltsin had pointed him as his successor. After this happened in 1999 in the presidential election, Putin got the vote of the 53 percent in 2000 and became the new president (Tellal, 2010: 195). Thus, as Putin has been undertaking the duties by procuration has officially taken the office and for Russia a new era has begun.

Putin's coming to power after the transition of the dismissal of the Soviet Union is significant for Russia. With Putin's period, Russia started to have a more active role in the international area and changed its foreign policy. This fact should be at hand while the Putin's coming to power and changes in Russia's foreign policy is examined in this part of the study. Putin, taking the office in 2000, pursued a foreign policy where it focuses on converting the unipolar world under the hegemony of the USA, in to a multi-polar world (Canar, 2012a: 22). Thus, a time will begin where Russia which has been in the transaction period after the Cold War, will stand out in the world as an effective actor.

Among Putin's aims, after having taken the command of Russia in 2000, was developing Russia in terms of economy and erasing the unpleasant effects of the bad economy that was inherited from the last days of the Soviet Union. Vladimir Putin, being aware of the necessity of fixing the international image of Russia to achieve that, has put an effort to fix the negative inheritance that Gorbachov has left for Yeltsin (Özden ve Cankara, 2007: 193-212). Thus, reducing the distance between Russia and the USA, and EU countries was intended.

Putin wanted to gain the Russian power again similar to its Soviet times and paid attention on the listed targets below.

i. Setting priorities in the foreign policy and putting effort for these priorities,

ii. Getting involved with the developments that take place around the world while pursuing Russia's interests,

iii. Developing strategic partnerships,

iv. Forming alternative unions against,

v. Improving and protecting Russia's status,

vi. Pursuing a multi-tasking political view,

vii. Improving the international status of Russia.

In order to analyze healthily the Putin's taking over the office and its reflection on the foreign policy, we must notice the negative indications before his time. The first matter that would show up before Putin's time was the unsteady cabinet. Yeltsin changing the government very often has caused this. In addition to this, an undeveloped democracy, collapsed economy, negative social life, increase of domestic and international debts were among the problems before Putin. Also, the Chechnya matter, relations with Europe, the bad course of the economy is main issues when Putin took over the office (Hekimoğlu, 2007: 78). That is why these factors were decisive for the foreign policy of Putin when he began leading Russia

In his first term of his leadership Putin has acted to strengthen the central power and was exposed to contacts from the West, especially by the USA. But in his second term for the measures he took to strengthen the central power against then Chechen terror that took place in Beslan had received harsh criticism from the USA" (Yapıc1, 2010: 216). These events may be considered as Russia becoming more powerful in terms of economy and politics in Putin's time. Thus, it could be 
understood that political and economic events took place with Putin starting to lead Russia have affected the foreign policy.

In Putin's term, some changes have begun in Russia's structure. With Putin taking over the office, Russia has gained a more centralist, more authoritarian and a better organized structure. In addition to this, Russia has begun to obtain the power in several sectors such as energy (Kotz, Weir, 2012: 432). This is the main reason why Russia developed when Putin was in power.

Even though a partnership was exercised to combat terrorism after the September $11^{\text {th }}$ attacks in 2001, this partnership came to an end with the USA's invasion on Iraq. Other than a brief collaboration against terrorism, Russia's relations with the USA was mostly based on competition. Relations with the EU countries remained remote. All these are considered as the result of Russia gaining power. As a matter of fact, the reason why the relations with the USA became second important is considered as the result of this (A $\breve{g r}, 2010: 87$ ).

One of the elements that needs to be mentioned about Putin's approach on relations with the USA is about the nuclear attempts. Being prepared against the USA's nuclear attempts is among the policies of Putin. It is not possible to overlook the effects of this policy on the relations with the USA. The USA's hegemony presenting itself with nuclear attempts as well has been disturbing for Russia and this fact has affected Putin's approach on relations with the USA.

The expansion of NATO was one of the factors that have affected Russia's approach with the USA in Putin's time. According to this fact as NATO expanded Russia was left out of the international system which caused it to be pushed away to the opposite side with its relations with the USA (Aktürk, 2012: 77). Thus, it can be said that this development inevitably has caused effects Russia's approach on relations with the USA in Putin's term. While NATO's attempts of expansion continue knowing these facts will be helpful understanding the developments occurring today; because these statements are building the base for the developments.

Another fact that has affected Putin's approach to the relations with the USA is the impression at the first half of the 2000's that Russia is surrounded. According to this, Russia which suffers a great loss with the occupation of Iraq did not welcome the governmental changes in Georgia, Ukraine and Kirghizstan in 2003-2005. Since the changes came with a major influence of the USA, Russia felt that it is being surrounded in the region. Thus, Putin's approach to relations with the USA was affected greatly from these events.

Central Asia is considered to be a topic that has significant effects on the relations between the USA and Russia. Russia has noticed that it was a mistake not building good relations with the countries in the region which have gained their independence with the dismissal of the Soviet Union; and in Vladimir Putin's time it had attempts in order to build good relations with the Central Asia countries. At this point the USA's influence has been continuing since they have gained their independence which means another matter of competition among both parties. Having the region rich of energy sources have caused interest of the USA be driven to the countries and the sources of energy in the region (Kamalov, 2011: 62). More importantly increase of the USA's influence in the region means the limitation of Russia's and China's influence in the region. Thus, all these developments represent Putin's approach to the relations with the USA.

It could be said that Russia's approach on the relations with the USA in Putin's time has been defined by the effects on interests of the activities of both countries commit in the world instead of the interactions and developments. Russia and the USA, taking steps according to their different interests in Central Asia, Caucasia, and Eastern Europe and in the Middle East consequently have affected Putin's approach on the relations with the USA. These statements which were used at the first term when Putin took over the office, today continue to show themselves such as in Syria about the developments while acting on account of different interests.

One of the facts that effected Putin's approach to the relations with the USA is that he led a Europe based policy. Putin has aimed to decrease the influence of the USA and to increase Russia's influence in the region by developing relations with the European countries.

Establishment of missile defense and the radar system in both Poland and the Czech Republic and agreement with NATO member Turkey to place a sophisticated missile tracking radar atop a high mountain in the Kürecik district of Malatya province in south-eastern Turkey. Though the Pentagon insists its radar is pointed at Iran. 
Early-warning radar system in Turkey, according to the information unveiled at NATO's summit in Chicago in May 2012. USA says missile system currently being developed to eliminate the potential Iranian threat.

Russia examined the plans of Patriot Missile Defense Systems on the Turkish-Syrian border and he says, it is only another excuse. Hasan Firouzabadi, Chief of Staff of the Iranian Armed Forces said that, the cause of a new world war can be a possible deployment of Patriot missile defense systems on the border between Syria and Turkey. Furthermore, Russian Foreign Ministry Sergei Lavrov says Patriot System may cause new armed clashes and even a new global war, also Patriot system is a serious threat to many countries. According to General Leonid Ivashov, the new missile facility is created not for defense, but an attack either on Iran or Syria.

As this project is considered as a threat by Russia, its goal is expressed as diminishing Russia's influence in Asia by the USA. Because of this project the USA and Russia had many conflicts and the missile shield system project had an effect on the content of the USA-Russia relations for a significant period of time.

But Russia says a look at a map reveals how easily the focal direction could cover key Russian nuclear sites such as Stevastopol where the bulk of the Russian Navy's Black Sea Fleet is stationed or to the vital Russian Krasnodar radar installation.

For this reason, the Russian Federation will deploy in the west and the south of the country modern weapons systems that could be used to destroy the European component of the US missile defense," Russia announced: "One of these steps could be the deployment of the Iskander missile systems in Kaliningrad.

\section{Conclusion}

Activating missile shield system in the Eastern Europe has been one of the matters that have affected Putin's approach on relations with the USA. Even though the USA expressed the matter as a project against the nuclear threats from Iran and North Korea, Russia insisted to claim that the project was about itself and objected its implementation to the end.

NATO's expansion is another important matter within the scope of Putin's approach to relations. According to Russia, NATO is a foundation under the USA control, and thus, acts to limit Russian activities by surrounding it. The data those confirm Russian opinion on this matter are among the conclusions of the study. At this point, one can see that Russia in Putin's time has taken initiatives to prevent NATO's impacts especially on Central Asia.

Within the base of Russia's approach on relations with the USA, there lies taking actions against a world order where the USA leads alone. At this point, Russia has decided to race with the USA with economic partnerships and through foreign policy instead of an arms race. Thus, he has aimed to eliminate the influence of the USA in a certain level from the world that is under the hegemony of the USA.

It is possible to say that with the beginning of Putin period, Russia's foreign policy has changed to the better comparing to the past. In addition, Russia's foreign policy in Putin's time has enhanced the prestige of the country. Thus, it can be said that with the activities of the foreign policy of Russia in Putin's time boosted, the reputation also did become better.

\section{References}

Ağır, 2010 - A ğır, B.S. (2010). Rus Dış Politikasını Oluşturan İç Etkenler, accessed at 25.05.2016. [Electronic resource]. URL: http://www.usak.org.tr/images_upload/files/kitap.pdf [in Turkish]

Aron, 2013 - Aron Leon (2013). The Putin Doctrin Foreign Affairs. [Electronic resource]. URL: http://www.academia.edu/download/35015368/The_Putin_Doctrine.docx

Bölme, 2010 - Bölme Selin M. (2010). NATO Zirvesi ve Füze Kalkanı Projesi, Ankara: SETA, Aralık, P. 5 .

Canar, 2012a - Canar, B. (2012). Soğuk Savaş sonrasında Amerika Birleşik Devletleri'nin Karadeniz Politikası. Ankara Üniversitesi Siyasal Bilgiler Fakültesi, Cilt 67, Sayı 1, pp. 49-80. [in Turkish]

Canar, 2012b - Canar, B. (2012). Rusya Federasyonu'nun Azerbaycan ile İlişkileri. Çankırı Karatekin Üniversitesi İktisadi ve İdari Bilimler Fakültesi Dergisi, Cilt 2, Sayl 1, pp. 21-38. [in Turkish] 
Cordesman et al., 2013 - Anthony H. Cordesman, Bryan Gold, Sam Khazai, and Bradley Bosserman (2013). U.S. and Iranian Strategic Competition: Sanctions, Energy, Arms Control, and Regime Change. CSIS, Washington DC.

Engdahl - Engdahl F. William. Why Moscow doesn't believe Washington on Misilse Defense... [Electronic resource]. URL: http://www.voltairenet.org/article172030.html

Göngen, 2014 - Göngen, M.A. (2014). Arap Baharı Karşısında ABD’nin Tutumu. Süleyman Demirel Üniversitesi Sosyal Bilimler Dergisi, Sayı 33, pp. 1-18. [in Turkish]

Gözen, 1997 - Gözen, R. (1997). Soğuk Savaș Sonrası Dönemde Uluslararası İlişkiler: Küreselleşme Perspektifi. Liberal Düşünce Dergisi, Cilt. 2, Sayı. 7, pp. 74-91. [in Turkish]

Hekimoğlu, 2007 - Hekimoğlu, A.N. (2007). Rusya’nın Dış Politikası, Ankara: Vadi Yayınları. [in Turkish]

Kamalov, 2009 - Kamalov, $\dot{I}$. (2009). Başkan Barack Obama ve Rusya-ABD İlişkilerinin Geleceği. Ortadoğu Analiz, Cilt 1, Sayı 2, pp. 65-72. [in Turkish]

Kotz, Weir, 2012 - Kotz, D.M., Weir, F. (2012). Gorbaçov'dan Putin'e Rusya'nın Yolu. Çeviri: Cemile Çakır, İstanbul, Kalkedon Yayınları. [in Turkish]

Kozin, 2012 - Kozin V. (2012). US-NATO Sea-based Missile System Threatens Russia, Global Research, March 31.

Kurt, 2014 - Kurt, S. (2014). Soğuk Savaş Sonrası ABD’nin Ortadoğu Politikası. Tarih Okulu Dergisi, Cilt 7, Sayı 19, pp. 167-196. [in Turkish]

Lulko, 2013 - Lulko Lyuba (2013). USA's missile defense system in Europe takes U-turn.

Pravda.Ru [Electronic resource]. URL: http://english.pravda.ru/world/americas/13-022013/123776missile_defense_europe-o/

NATO - NATO Lisbon Summit Declaration. November 20, 2010 [Electronic resource]. URL: https://www.nato.int/cps/en/natolive/official_texts_68828.htm

Özkan, 2010 - Özkan, G. (2010). Soğuk Savaş Sonrası Orta Asya ve Kafkasya Ekseninde Türkiye-NATO-Rusya İlişkileri ve Türk Dış Politikasına Yansımaları. Gazi Üniversitesi İktisadi ve İdari Bilimler Fakültesi Dergisi, Cilt 12, Sayı 1, pp. 109-132. [in Turkish]

Özkan, 2011 - Özkan, B. (2011). Soğuk Savaş Sonrası Amerikan Dış Politikası. Stratejik Araşturmalar Dergisi, Cilt 9, Sayı 16, pp. 51-91. [in Turkish]

Rozoff Rick - Rozoff Rick. NATO Expansion, Missile Deployments And Russia'sNew Military

Doctrine [Electronic resource]. URL: http://www.voltairenet.org/article164065.html

Stent, 2012 - Stent, A. (2012). U.S. - Russia Relations in the Second Obama Administration,

[Electronic resource]. URL: https://www.brookings.edu/articles/u-s-russia-relations-in-thesecond-obama-administration/

Telatar, 2012 - Telatar, G. (2012). Barack Obama Yönetiminin İran'ın Nükleer Faaliyetlerine

Yönelik Politikası. Akademik Ortadoğu Dergisi, Cilt 7, Sayı 1, ss. 53-78. [in Turkish]

Tellal, 2010 - Tellal, E. (2010). Zümrüdüanka: Rusya Federasyonu'nun Dış Politikası. Ankara Üniversitesi Siyasal Bilgiler Fakültesi Dergisi, Cilt 65, Sayı 3, pp. 189-236. [in Turkish]

Vasılenkov, 2013 - Vasilenkov Sergei (2013). Will There Be World War Three? PravdaRu.

[Electronic resource]. URL: http://english.pravda.ru/world/americas/o8-01-2013/123402world_war_three-o/

ve Cankara, 2007 - Özden C. P. ve Cankara, Y. (2007). Vladimir Putin Döneminde Rus Dış Politikasında Yapılan Değişiklikler. Süleyman Demirel Üniversitesi Fen Edebiyat Fakültesi Dergisi, Sayl 15, pp. 193-212. [in Turkish]

Zaks, 2012 - Zaks Dmitry (2012). Russia Tests New Missile After NATO Summit,” Agence France-Presse, May 23. [Electronic resource]. URL: www.defensenews.com/article/20120523/ DEFREG01/305230003/Russia-Tests-New-Missile-After-NATO-Summit 